\title{
Vasorelaxing and antihypertensive activities of synthesized peptides derived from computer-aided simulation of pepsin hydrolysis of yam dioscorin
}

\author{
Yin-Shiou Lin', Yeh-Lin Lu², Guei-Jane Wang ${ }^{3,4,5}$, Hong-Jen Liang ${ }^{6,7^{*}}$ and Wen-Chi Hou ${ }^{1,7^{*}}$
}

\begin{abstract}
Background: We reported that yam dioscorin and its peptic hydrolysates exhibited ACE inhibition and antihypertensive effects on SHRs, however, the active peptides are not really isolated until now. Using ACE inhibitory screenings, two penta-peptides, KTCGY and KRIHF, were selected for ex vivo and in vivo experiments.

Results: KTCGY, KRIHF, and captopril were shown to have similar vasodilating effects against phenylephrine (PE)-induced tensions in rat endothelium-dependent thoracic aortic rings, however, KTCGYKTCGY (two-repeated KTCGY) and TCGYTCGY (two-repeated TCGY) were showed endothelium-independent vasodilating effects against PE-induced tensions. KTCGY, KRIHF (10 or $20 \mathrm{mg} / \mathrm{kg}$ ), and captopril $(10 \mathrm{mg} / \mathrm{kg}$ ) were used to evaluate antihypertensive activity during 24-h after a single oral administration to spontaneously hypertensive rats (SHRs). The KTCGY and KRIHF showed significantly different and reduced the systolic blood pressure of SHRs compared to the blank.
\end{abstract}

Conclusions: These results suggest that KTCGY and KRIHF may contribute important roles in yam dioscorin for regulating blood pressure in vivo.

Keywords: Angiotensin converting enzyme; Antihypertensive activity; Blood pressure; Vasorelaxing; Yam dioscorin

\section{Background}

Processed yam tuber is a traditional Chinese medicine used as a juvenescent substance, with no apparent side effects resulting from long-term use, which is ranked the top levels in Chinese Pharmacopoeia. Yams (Dioscorea spp., Dioscoreaceae) are an important tuber crop in Africa, Asia, and Middle and South America and are also a staple food in the Caribbean. Yam dioscorin and its peptic hydrolysates have been reported to exhibit several biological activities in vitro and in vivo (Lu et al. 2012), including antioxidant (Hou et al. 2001; Liu et al. 2006; Han et al. 2013, 2014a,b), antihypertensive (Hsu et al. 2002; Lin et al. 2006; Liu et al. 2009a), immunomodulatory (Liu et al. 2007; Liu et al. 2009b), and enzyme activities (Hou et al. 1999a, b; Hou et al. 2000).

The untreated high blood pressure is considered to be the central factor in stroke which accounts approximately

\footnotetext{
* Correspondence: jenliang@mail.ypu.edu.tw; wchou@tmu.edu.tw ${ }^{6}$ Department of Food Science, Yuanpei University, Hsinchu, Taiwan ${ }^{1}$ Graduate Institute of Pharmacognosy, Taipei Medical University, Taipei, Taiwan

Full list of author information is available at the end of the article
}

33\% deaths (Mark and Davis 2000). There are several classes of pharmacological agents which have been used in the treatment of hypertension, and one class of antihypertensive drugs known as angiotensin I converting enzyme (ACE) inhibitors is associated with a low rate of adverse side effects and is the preferred class of antihypertensive agents when treating patients with concurrent secondary diseases or cardiovascular diseases (Zaman et al. 2002). ACE (peptidyldipeptide hydrolase, EC 3.4.15.1) is a dipeptide-liberating $\mathrm{Zn}$-containing exopeptidase, which removes a dipeptide from the $\mathrm{C}$-terminus of angiotensin $\mathrm{I}$ to form angiotensin II, a very hypertensive compound. Several ACE inhibitory peptides were isolated from food proteins and exhibited generally to reduce blood pressures of SHRs (Martínez-Maqueda et al. 2012). Fujita et al. (2000) found that the octapeptides of FFGRCVSP $\left(\mathrm{IC}_{50}=\right.$ $0.4 \mu \mathrm{M})$ and ERKIKVYL $\left(\mathrm{IC}_{50}=1.2 \mu \mathrm{M}\right)$ were potent $\mathrm{ACE}$ inhibitors, but none of them were effective in spontaneously hypertensive rats (SHRs) to reduce the blood pressure. These potential ACE inhibitory peptides were 
further hydrolyzed by the rat's gastrointestinal proteases and then lose their antihypertensive effects on SHR in vivo. We reported that yam dioscorin and its peptic hydrolysates exhibited ACE inhibitory activity (Hsu et al. 2002) and antihypertensive activity (Lin et al. 2006) using SHRs as models, however, the active peptides are not really isolated until now. In this study, using angiotensin converting enzyme inhibition as preliminary screenings, two out of twenty-three synthesized peptides from a computer-aided simulation of pepsin hydrolysis of yam dioscorin were selected for further ex vivo and in vivo experiments and captopril was used for comparisons. It is suggested that KTCGY and KRIHF show vasodilating effects and can reduce SHR's systolic blood pressure (SBP) which may contribute important roles in yam dioscorin for regulating blood pressure in vivo.

\section{Methods}

\section{Materials}

The 23 peptides for ACE inhibitory activity screenings were synthesized by Mission Biotech. (Taipei, Taiwan). Peptides for ex vivo and in vivo experiments used in this study (KTCGY, KTCGYKTCGY, TCGYTCGY, and KRIHF) were synthesized by Shanghai Hanhong Chemical Co., Ltd (Shanghai, China) or Shanghai Mocell Biotech Co., Ltd (Shanghai, China). The purity of each peptide was determined to be greater than $97 \%$ by performing HPLC chromatography and mass spectroscopy. Captopril was purchased from Calbiochem Co. (CA, USA). $\mathrm{N}$-(3-[2furyl]acryloyl]-Phe-Gly-Gly (FAPGG), ACE (I unit, rabbit lung), dimethyl sulfoxide (DMSO) were purchased from Sigma Chemical Co. (St. Louis, MO, USA). Other chemicals and reagents were from Sigma Chemical Co. (St. Louis, MO, USA).

\section{Computer-aided simulation of pepsin hydrolysis of yam dioscorin}

The deduced sequences of dioscorin A (UniProtKB/ TrEMBL:Q9M519) and dioscorin B (UniProtKB/TrEMBL: Q9M501) were selected from the website of the ExPASy SIB Bioinformatics Resource Portal (http://www.expasy. org/proteomics) to participate in a computer-aided simulation of pepsin hydrolysis $(\mathrm{pH}>2)$ (http://web.expasy. org/peptide_mass/). Twenty-three peptides were selected for syntheses following the general rules which the peptide contained aromatic or branched-chain aliphatic amino acids closed to the $\mathrm{COOH}$-terminus for ACE inhibitions (Cheung et al. 1980), including (1) KTCGNGME, (2) PPCSE, (3) CDDRVIRTPLT, (4) KTCGY, (5) PPCTE, (6) RDNGVIF, (7) KRIHF, (8) RRDY, (9) RSVF, (10) PTNF, (11) GISW, (12) MGSF, (13) VSIL, (14) HSPA, (15) DPF, (16) RY, (17) RF, (18) NW, (19) RL, (20) GVI, (21) GSL, (22) SY, and (23) GPA.

\section{ACE inhibitory assay screenings}

The ACE inhibitory activity was measured following the previous reports with some modifications (Hsu et al. 2002). Each synthesized peptide was dissolved in DMSO to $4 \mathrm{mM}$ as stocks. The $1 \mathrm{ml}, 0.5 \mathrm{mM}$ FAPGG (dissolved in $50 \mathrm{mM}$ Tris- $\mathrm{HCl}$ buffer, $\mathrm{pH} 7.5$, containing $0.3 \mathrm{M}$ $\mathrm{NaCl}$ ) was mixed with $12.2 \mu \mathrm{l}$ peptide solution, and then twenty $\mu \mathrm{l}(20 \mu \mathrm{U})$ of commercial ACE (stock solution, $1 \mathrm{U} / \mathrm{ml}$ ) was added. The $0.1 \%$ DMSO solution was used instead of sample solution for blank experiments $\left(\Delta \mathrm{A}_{\text {blank }} / \mathrm{min}\right)$. The decreased absorbance at $345 \mathrm{~nm}$ $\left(\Delta \mathrm{A}_{\text {sample }} / \mathrm{min}\right)$ was recorded during $90 \mathrm{sec}$ at room temperature. The ACE inhibition (\%) was calculated as followed: $\left[1-\left(\Delta \mathrm{A}_{\text {sample }} / \mathrm{min} \div \Delta \mathrm{A}_{\text {blank }} / \mathrm{min}\right)\right] \times 100$.

\section{Effects of KTCGY, KTCGYKTCGY, TCGYTCGY, and KRIHF on phenylephrine-induced tensions in rat thoracic aortic ring ex vivo}

Effects of four peptides and captopril on vascular tension were examined following the previous method (Wang et al. 2001). Male Sprague-Dawley rats were killed by decapitation, and sections of the thoracic aorta between the aortic arch and the diaphragm were excised carefully and placed in a Petri dish with oxygenated Krebs' buffer $(120 \mathrm{mM} \mathrm{NaCl}, 4.5 \mathrm{mM} \mathrm{KCl}, 2.5 \mathrm{mM} \mathrm{CaCl} 2,1 \mathrm{mM}$ $\mathrm{MgSO}_{4}, 27 \mathrm{mM} \mathrm{NaHCO}, 1 \mathrm{mM} \mathrm{KH} \mathrm{PO}_{4}, 10 \mathrm{mM}$ glucose, $\mathrm{pH} 7.4$, with $95 \% \mathrm{O}_{2}, 5 \% \mathrm{CO}_{2}$ ) and gently dissected free of fat and connective tissue. The endothelium was removed by gently rubbing the intimal layer of the vessel with a wire. The isolated aortic rings, 3 to $4 \mathrm{~mm}$ in length with or without the endothelium, were fixed isometrically in organ chambers under passive tension $(1.8 \mathrm{~g})$ for $60 \mathrm{~min}$. Changes in vascular tension were recorded with a polygraph (Gould, model 2400, Valley View, OH, USA) via a force displacement transducer (Grass FT03, Quincy, MA, USA). After equilibration, the near maximal concentration was induced by $\mathrm{PE}(0.3 \mu \mathrm{M})$. When the rings achieved a stable tension, the acetylcholine $(3 \mu \mathrm{M})$ was added to the bath to assess endothelial integrity. The relaxing effects of KTCGY, KTCGYKTCGY, TCGYTCGY, KRIHF, and captopril on PE $(0.3 \mu \mathrm{M})$ pre-contracted endothelium-intact or endothelium-denuded aortic rings were examined. When PE treatments reached a steady plateau (considered as 100\%), KTCGY, KTCGYKTCGY, TCGYTCGY, KRIHF, and captopril were then tested at cumulative concentrations $(0.1$ to $100 \mu \mathrm{M})$ for their ability to induce aortic ring relaxations.

\section{Antihypertensive Effects of KTCGY, KRIHF, and captopril in SHRs}

Experimental procedures were reviewed and approved by the Institutional Animal Care and Use Committee of Taipei Medical University (LAC-95-0076, LAC-97-0117, and LAC-100-0038). Male SHRs (18-28 weeks old; from 
National Laboratory Animal Center, Taipei, Taiwan) were housed individually in steel cages kept at $24^{\circ} \mathrm{C}$ under a 12-h light-dark cycle, with free access to water and a standard mouse/rat chow (Prolab ${ }^{\oplus}$ RMH2500, 5P14 Diet, PMI Nutrition International Brentwood, MO, USA). SHRs were randomly divided into 4 groups $(\mathrm{N}=6$ of each group), KTCGY or KRIHF at concentration of $10 \mathrm{mg} / \mathrm{kg}$ and $20 \mathrm{mg} / \mathrm{kg}$ was orally administered to the SHRs, and the SBP were measured after $0,2,4,6,8$, and $24 \mathrm{~h}$ by using an indirect tail-cuff blood pressure meter (BP98-A, Softron, Tokyo, Japan). Distilled water $(0.5 \mathrm{ml})$ was administered to the SHRs in the blank group. The captopril $(10 \mathrm{mg} / \mathrm{kg})$ was used as the positive control.

\section{Statistical analysis}

Data were expressed as mean \pm S.D. For animal experiments, the differences between the blank and the experimental group at the same time was analyzed using Student's $t$-test, and the $P$-value of less than $0.05{ }^{*}$ ), $\left.0.01{ }^{* * *}\right)$, and $0.001(* *)$ were recognized as different significantly. The statistical analysis was performed using the SigmaPlot software 10.0.

\section{Results}

\section{ACE inhibitory assay screenings}

The deduced sequences of dioscorin A (UniProtKB/ TrEMBL:Q9M519) were selected for computer-aided simulation of pepsin hydrolysis $(\mathrm{pH}>2)$. There were sixty-four peptide fragments and seven amino acid residues (A, L, Q, E, F, Y, and W) were released from dioscorin A in a computer-aided simulation hydrolysis (Additional file 1: Figure S1). The deduced sequences of dioscorin B (UniProtKB/TrEMBL:Q9M501) were selected for simulation of pepsin hydrolysis $(\mathrm{pH}>2)$. There were sixty-five peptide fragments and eight amino acid residues (A, I, L, $\mathrm{Q}, \mathrm{E}, \mathrm{F}, \mathrm{Y}$, and $\mathrm{W}$ ) were released from dioscorin $\mathrm{B}$ in a computer-aided simulation hydrolysis (Additional file 1: Figure S2). Following the general rules which the peptide contained aromatic or branched-chain aliphatic amino acids closed to the $\mathrm{COOH}$-terminus for ACE inhibitions (Cheung et al. 1980), the twenty-three peptides were selected for syntheses in order to test ACE inhibitory activity. In assay system, the substrate FAPGG was hydrolyzed by ACE to generate FAP and dipeptide GG released, and the absorbance at $345 \mathrm{~nm}$ was decreased. From the results of Figure 1, under the same concentration of $40 \mu \mathrm{M}$ for each peptide, the KTCGY (No.4) and KRIHF (No. 7) showed the first two potent ACE inhibitory peptides among 23 synthesized peptides. The KTCGY and KRIHF with higher than $50 \%$ ACE inhibitory activity were selected for further ex vivo and in vivo antihypertensive experiments. Table 1 showed the information of KTCGY and KRIHF in yam dioscorin.

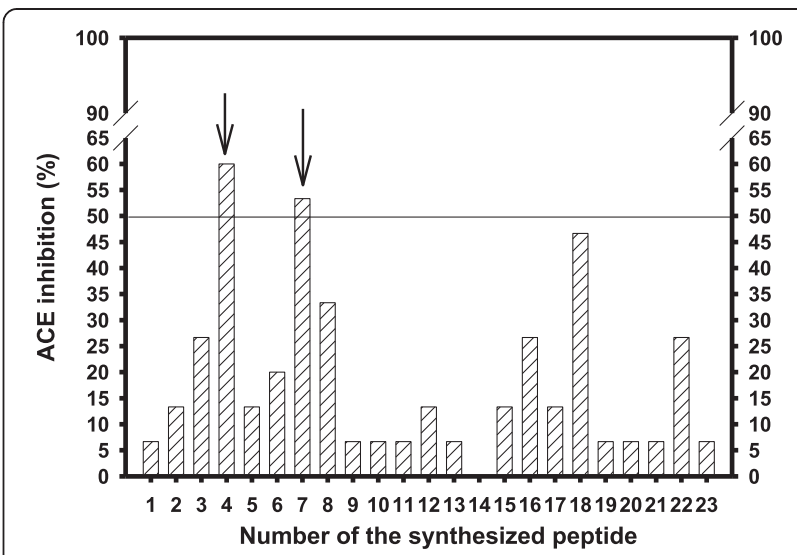

Figure 1 ACE inhibition by 23 synthesized peptides $(40 \mu \mathrm{M})$ derived from a computer-aided simulation of pepsin hydrolysis of yam dioscorin. The $0.1 \%$ DMSO solution was used instead of sample solution for blank experiments $\left(\Delta \mathrm{A}_{\text {blank }} / \mathrm{min}\right)$. The decreased absorbance at $345 \mathrm{~nm}\left(\Delta \mathrm{A}_{\text {sample }} / \mathrm{min}\right)$ was recorded during $90 \mathrm{sec}$ at room temperature. The ACE inhibition (\%) was calculated as followed: $\left[1-\left(\Delta \mathrm{A}_{\text {sample }} / \mathrm{min} \div \Delta \mathrm{A}_{\text {blank }} / \mathrm{min}\right)\right] \times 100$. The synthesized peptides included (1) KTCGNGME, (2) PPCSE, (3) CDDRVIRTPLT, (4) KTCGY, (5) PPCTE, (6) RDNGVIF, (7) KRIHF, (8) RRDY, (9) RSVF, (10) PTNF, (11) GISW, (12) MGSF, (13) VSIL, (14) HSPA, (15) DPF, (16) RY, (17) RF, (18) NW, (19) RL, (20) GVl, (21) GSL, (22) SY, and (23) GPA. Arrow indicated peptide with ACE inhibition over $50 \%$.

Relaxations in rat thoracic aortic ring with or without endothelium ex vivo

Except from two penta-peptides of KTCGY and KRIHF, KTCGYKTCGY (two-repeated KTCGY) and TCGYTCGY (two-repeated TCGY) were also synthesized for ex vivo aortic ring vasodilating experiments and captopril was used for comparisons. It was found that KTCGY, KRIHF, and captopril showed endothelium-dependent, but not endothelium-denuded, aortic ring relaxations in PE-induced tensions (Figure 2A, D, and E). When $100 \mu \mathrm{M}$ of KTCGY, KRIHF, or captopril was added, the PE-induced aortic ring tension was markedly reduced from $100 \%$ to $(26.97 \pm 7.48) \%$, $(19.19 \pm 7.63) \%$ or $(26.81 \pm 5.54) \%$, respectively. Only KRIHF at $10 \mu \mathrm{M}$ could reduce PEinduced aortic ring tensions from $100 \%$ to $(80.26 \pm 7.82) \%$.

Table 1 The synthesized peptides derived from computer-aided simulation of pepsin hydrolysis ${ }^{a}$ of yam dioscorin $^{\mathrm{b}, \mathrm{c}}$ with potential angiotensin converting enzyme inhibitory activities used in this study

\begin{tabular}{llll}
\hline $\begin{array}{l}\text { Synthesized } \\
\text { peptide no. }\end{array}$ & $\begin{array}{l}\text { Peptide } \\
\text { sequence }^{\mathbf{a}}\end{array}$ & $\begin{array}{l}\text { Protein } \\
\text { sources }^{\mathbf{b}, \mathbf{c}}\end{array}$ & $\begin{array}{l}\text { Molecular mass } \\
\text { (Average mass, Da) }\end{array}$ \\
\hline 4 & KTCGY & dioscorin B (52-56) & 570.66 \\
7 & KRIHF & dioscorin A (118-122) & 699.85 \\
& & dioscorin B (118-122) & \\
\hline
\end{tabular}

a) PeptideMass tool in Proteomics (http://web.expasy.org/peptide_mass/) of ExPASy: SIB Bioinformatics Resource Portal (http://www.expasy.org) website. b) Dioscorin A from UniProtKB/TrEMBL:Q9M519;

c)Dioscorin B from UniProtKB/TrEMBL:Q9M501. 

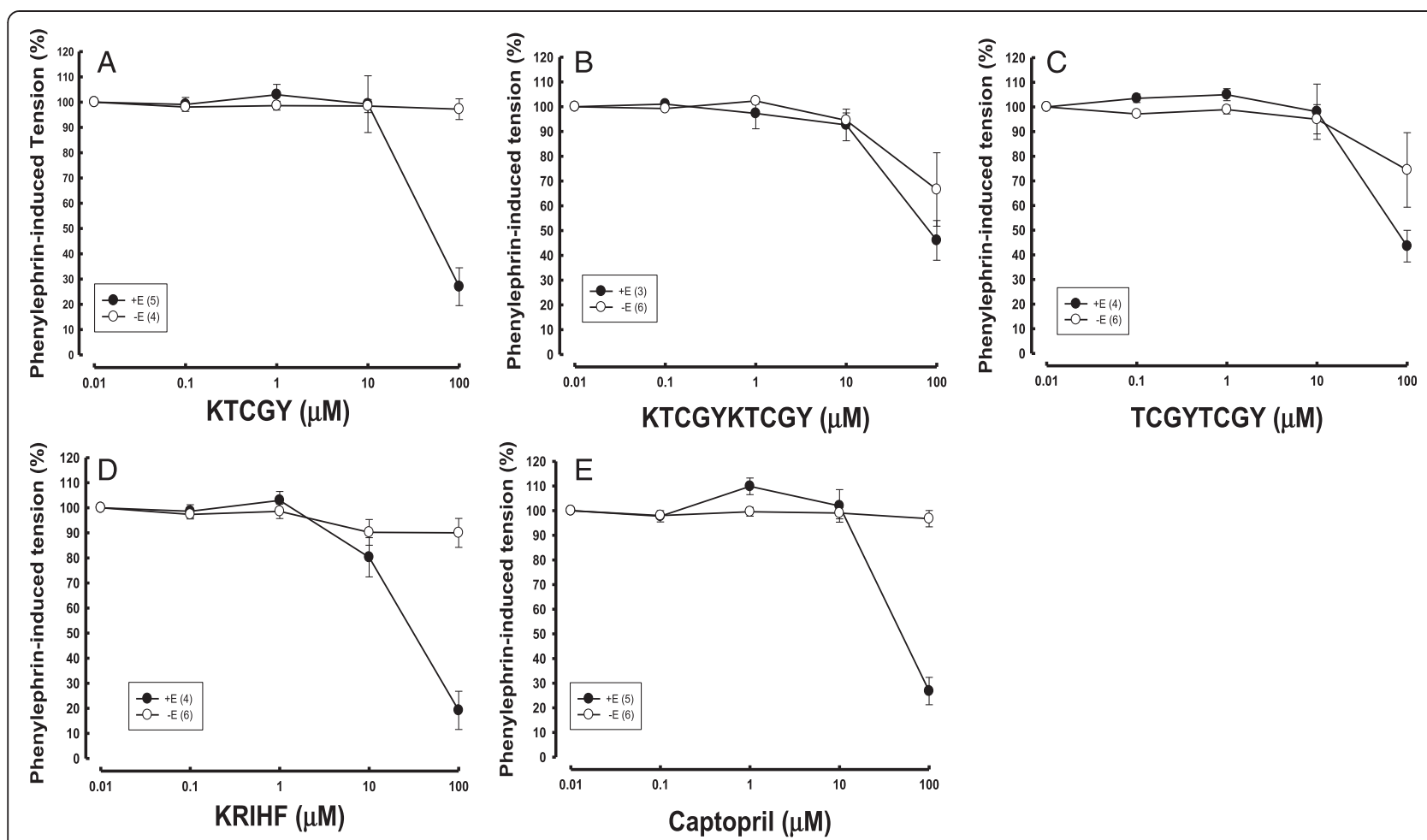

Figure 2 Vasorelaxing activity of endothelium-intact and endothelium-denuded SD rat aortic rings in phenylephrine-induced tensions. (A) KTCGY, (B) KTCGYKTCGY, (C) TCGYTCGY, (D) KRIHF, and (E) captopril on Data were expressed as mean \pm S.E.

However, KTCGYKTCGY and TCGYTCGY showed endothelium-independent aortic ring relaxations in PE-induced tensions (Figure 2B and C). When $100 \mu \mathrm{M}$ of KTCGYKTCGY or TCGYTCGY was added, the PEinduced endothelium-intact aortic ring tension was markedly reduced from $100 \%$ to $(46.05 \pm 8.02) \%$ or $(43.52 \pm$ $6.42) \%$, respectively; under the same $100 \mu \mathrm{M}$ concentration, KTCGYKTCGY or TCGYTCGY reduced the PE-induced endothelium-denuded aortic ring tension from 100\% to $(66.59 \pm 14.84) \%$ or $(74.44 \pm 15.13) \%$, respectively.

\section{Antihypertensive activity in vivo}

The KTCGY or KRIHF (10 or $20 \mathrm{mg} / \mathrm{kg}$ ) was orally administered once and the SBP was measured at 2-, 4-, 6-, 8-, and 24-h, and the captopril (10 $\mathrm{mg} / \mathrm{kg}$ ) was used for comparisons. Figure 3A shows the SBP changes of SHR after KTCGY oral administration during $24 \mathrm{~h}$. It was found that KTCGY at 10 or $20 \mathrm{mg} / \mathrm{kg}$ showed dosedependently antihypertensive activity by lowing SBP and showed significantly different compared to the blank at 6-h $(P<0.01)$ and 8 -h $(P<0.01)$ for $10 \mathrm{mg} / \mathrm{kg}$ and at 2 -h $(P<0.05)$, 4-h $(P<0.001), 6$-h $(P<0.001), 8-\mathrm{h}(P<0.001)$ for $20 \mathrm{mg} / \mathrm{kg}$. The average reduced SBP for $10 \mathrm{mg} / \mathrm{kg}$ at 6-h and 8-h was 24.17 and $11.93 \mathrm{mmHg}$, respectively; the average reduced SBP for $20 \mathrm{mg} / \mathrm{kg}$ at 2-h, 4-h, 6-h, and 8-h was $24.20,26.24,31.03$, and $21.40 \mathrm{mmHg}$, respectively. The positive control of captopril $(10 \mathrm{mg} / \mathrm{kg})$ showed antihypertensive activity by lowing SBP and showed significantly different compared to the blank at 2 -h $(P<0.001)$, 4-h $(P<0.01)$, 6-h $(P<0.001)$, 8-h $(P<0.01)$, and 24 -h $(P<0.05)$. The average reduced SBP for captopril $(10 \mathrm{mg} / \mathrm{kg})$ at $2-\mathrm{h}, 4-\mathrm{h}, 6-\mathrm{h}, 8-\mathrm{h}$, and $24-\mathrm{h}$ was 26.85 , $24.97,29.82,24$, and $13.80 \mathrm{mmHg}$, respectively. It was noted that KTCGY at $20 \mathrm{mg} / \mathrm{kg}$ showed similar antihypertensive activity to captopril at $10 \mathrm{mg} / \mathrm{kg}$. Figure $3 \mathrm{~B}$ shows the SBP changes of SHR after KRIHF oral administration during $24 \mathrm{~h}$. It was found that KRIHF at 10 or $20 \mathrm{mg} / \mathrm{kg}$ showed dose-independently antihypertensive activity by lowing SBP and showed significantly different compared to the blank at 2 -h $(P<0.05), 4$-h $(P<0.01)$, 6-h $(P<0.01)$ and 8 -h $(P<0.01)$ for $10 \mathrm{mg} / \mathrm{kg}$ and at 2 -h $(P<0.01)$, 4-h $(P<0.05), 6$-h $(P<0.01)$, 8 -h $(P<0.01)$ for $20 \mathrm{mg} / \mathrm{kg}$. The KRIHF at dose of 10 and $20 \mathrm{mg} / \mathrm{kg}$ showed similar antihypertensive activities toward SHRs. The average reduced SBP for $10 \mathrm{mg} / \mathrm{kg}$ at 2-h, 4-h, 6-h, and 8-h was 17.30, 21.95, 21.47, and $16.65 \mathrm{mmHg}$, respectively; the average reduced SBP for $20 \mathrm{mg} / \mathrm{kg}$ at 2-h, 4-h, 6-h, and 8-h was 18.57, 19.64, 20.87, and $8.99 \mathrm{mmHg}$, respectively.

\section{Discussion}

The present ex vivo and in vivo data showed KTCGY and KRIHF with vasodilating effects against PE-induced endothelium-intact aortic tensions and lowering SHR's 

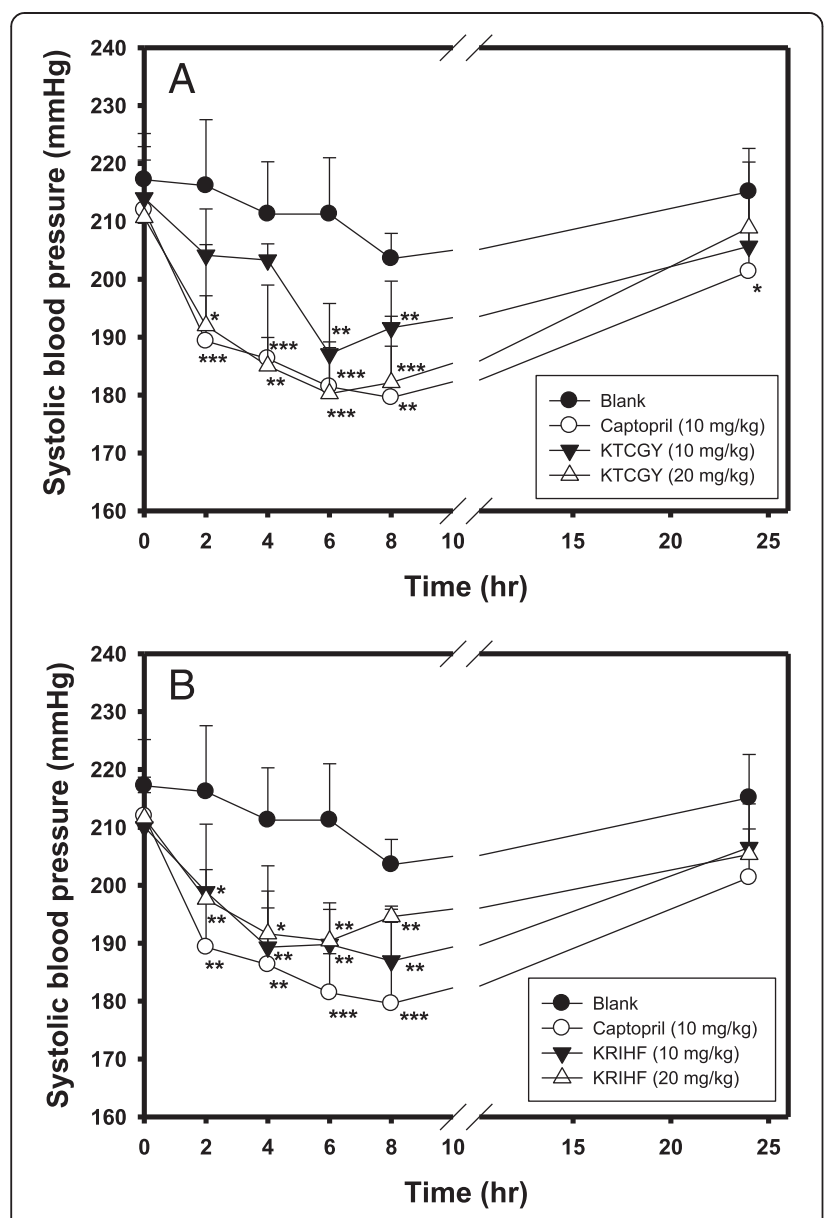

Figure 3 Antihypertensive activity of (A) KTCGY and (B) KRIHF on systolic blood pressure of spontaneously hypertensive rats (SHRs). KTCGY or KRIHF at concentration of $10 \mathrm{mg} / \mathrm{kg}$ and $20 \mathrm{mg} / \mathrm{kg}$ was orally administered to the SHRs (6 rats/group), and the SBP were measured after $0,2,4,6,8$, and $24 \mathrm{~h}$ by using an indirect tail-cuff blood pressure meter (BP98-A, Softron, Tokyo, Japan). Distilled water (0.5 ml) was administered to the SHRs in the blank group. The captopril $(10 \mathrm{mg} / \mathrm{kg})$ was used as the positive control. Data were expressed as mean \pm S.D. For animal experiments, the differences between the blank and the experimental group at the same time was analyzed using Student's t-test, and the $P$-value of less than $0.05\left(^{*}\right), 0.01\left(^{* *}\right)$, and 0.001 $\left.{ }^{(* *}\right)$ were recognized as different significantly.

SBP which were derived from a computer-aided simulation of pepsin hydrolysis of the yam tuber dioscorin. The penta-peptide of KTCGY was positioned at amino acid residue 52 to residue 56 of dioscorin $B$ protein (UniProtKB/TrEMBL:Q9M501, Fig. S2), and the pentapeptide of KRIHF was positioned at amino acid residue 118 to residue 122 of dioscorin A protein (UniProtKB/ TrEMBL:Q9M519, Fig. S1) and dioscorin B protein (UniProtKB/TrEMBL:Q9M501, Fig. S2). Conlan et al. (1995) first reported two classes of cDNA clones encoding major yam tuber storage proteins from Dioscorea cayenensis and named as dioscorin. We demonstrated that dioscorins from six cultivars of three Dioscorea species accounted over $90 \%$ of water-soluble proteins by immune stains (Hou et al. 2000). The processed yam tuber is a traditional Chinese medicine used as a juvenescent substance, with no apparent side effects after long-term uses; the tuber is involved in the top levels in a famous Chinese pharmacopoeia. It was recently reviewed that yam dioscorin and its peptic hydrolysates exhibited several biological activities in vitro and in vivo (Lu et al. 2012). It seems that yam or its major protein, dioscorin, may be potentials in developments of several aspects of functional food and needed further investigations.

From the present results of ACE inhibitory activity screenings (Figure 1), the orders of top 5 among 23 synthetic peptides were KTCGY (No.4) > KRIHF (No. 7) >

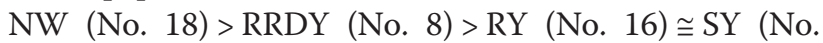
$22) \cong$ CDDRVIRTPLT (No. 3). These potent ACE inhibitory peptides were promised to the general rules which peptides contained aromatic or branched-chain aliphatic amino acids closed to the $\mathrm{COOH}$-terminus for $\mathrm{ACE}$ inhibitions (Cheung et al. 1980). The dioscorin peptic hydrolysates were reported to exhibit ACE inhibitory activity (Hsu et al. 2002) and antihypertensive activity (Lin et al. 2006) using SHR as models. Therefore, the synthetic KTCGY and KRIHF were used for ex vivo and in vivo experiments. KTCGY and KRIHF showed endothelium-dependent aortic ring relaxations in PEinduced tensions (Figure 2A, D) which the vasodilating effects were similar to ACE inhibitor, captopril (Figure 2E). The captopril is designed to inhibit ACE, one of important enzymes in renin-angiotensin system, to achieve antihypertension (Rubin et al. 1978). It was reported that captopril also showed endothelium-dependent rabbit aortic ring relaxations in PE-induced tensions, and the possible action mechanism might be from its superoxide radical scavenging activity of its structural sulfhydryl group (Mittra and Singh 1998). Hernández-Ledesma et al. (2005) reported that individual amino acids exhibited different oxygen radical absorbance capacity (ORAC) activities, such as $\operatorname{Trp}$ [W, 4.649 mole trolox equivalents (TE)/ $\mu$ mole], Tyr (Y, 1.574 $\mu$ mole TE/ $\mu$ mole), Met (M, 1.126

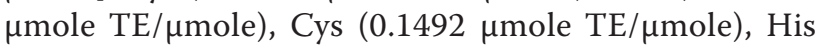
(H, $0.073 \mu$ mole TE/ $\mu$ mole), and Phe (F, $0.0025 \mu$ mole TE/ $\mu$ mole), which a Trp-indole group, Tyr-phenolic group, His-imidazole group, and Cys-sulfhydryl group served as hydrogen donors to contribute ORAC activity. It was reported that the ovokinin (2-7) (a hexa-peptide, RADHPF) isolated from chymotryptic ovalbumin hydrolysates exhibited dose-dependently nitric oxide-stimulated vaso-relaxations in endothelium-intact PE-induced tensions of SHR's mesenteric artery, however, ovokinin (2-7) showed less effect on $\mathrm{ACE}$ inhibition $\left(\mathrm{IC}_{50}\right.$ higher than $1 \mathrm{mM}$ ) (Matoba et al. 1999). Therefore, we propose that vaso-relaxing peptides of KTCGY and KRIHF in 
endothelium-intact aortic rings may involve radical scavenging and nitric oxide stimulating activities and need further investigations.

The KTCGYKTCGY and TCGYTCGY showed endothelium-intact and endothelium-denuded vaso-relaxing activities in PE-induced tensions which were different from the action mode of KTCGY of above-mentioned. The ovokinin (an octa-peptide, FRADHPFL) isolated from peptic hydrolysates of egg ovalbumin showed bradykinin B1 receptor antagonist and exhibited endothelium-independent canine mesenteric artery relaxations in prostaglandin F2 $\alpha$-induced tensions (Fujita et al. 1995). Recently, a series of experiments by Matsui team demonstrated that WH di-peptide showed endothelium-independent SD rat aortic ring relaxations in $\mathrm{KCl}$-induced contractions by suppressing $\mathrm{Ca}^{2+}$ influx (Tanaka et al. 2008), which the inhibition of extracellular calcium entry into vascular smooth muscle cells by blocking dihydropyridine-like L-type $\mathrm{Ca}^{2+}$ channels (Wang et al. 2010), and the inhibition against voltage-dependent L-type $\mathrm{Ca}^{2+}$ channels phosphorylation (Kobayashi et al. 2012). The HRW tri-peptide also showed endothelium-independent vaso-relaxing activities in PE-induced tensions by inhibiting extracellular $\mathrm{Ca}^{2+}$ influx (Tanaka et al. 2009). Therefore, it is proposed that KTCGYKTCGY and TCGYTCGY with endotheliumindependent vaso-relaxing activities in PE-induced tensions might involve $\mathrm{Ca}^{2+}$ influx and $\mathrm{Ca}^{2+}$ channels and needed investigations further.

From the present results of in vivo SHR oral administration, both penta-peptides of KTCGY and KRIHF at doses of 10 and $20 \mathrm{mg} / \mathrm{kg}$ exhibited antihypertensive activities by lowering SBP, but not diastolic blood pressure (data not shown), among which KTCGY of $20 \mathrm{mg} / \mathrm{kg}$ exhibited the similar lowering SBP profile to captopril of $10 \mathrm{mg} / \mathrm{kg}$ after a single oral administration. However, the vasorelaxing peptide with antihypertensive activity is not necessary for potent ACE inhibition. Therefore, it might loss some antihypertensive peptides from ACE inhibitory screenings in the present study. The RF di-peptide (Kagebayashi et al. 2012) and IHRF tetra-peptide (Kontani et al. 2014) isolated from rice glutelin with lower ACE inhibition was reported to exhibit cholecystokinindependent vaso-relaxing and antihypertensive activities in SHR, which the RF di-peptide was the same as No. 17 synthesized peptide in Figure 1 of less ACE inhibitory activity in the present study from computer-aided simulation of pepsin hydrolysis of yam dioscorin A (residues of 134-135 and 158-159) and yam dioscorin B (residues of 158-159). However, these results provide evidences to support yam dioscorin after ingestion for blood pressure regulations.

\section{Conclusions}

The KTCGY and KRIHF show vasodilating effects and can reduce SHR's systolic blood pressure which may contribute important roles in yam dioscorin for regulating blood pressure in vivo and will be beneficial for antihypertension in functional food preparations.

\section{Additional file}

Additional file 1: Figure S1. The computer-aided simulation of pepsin hydrolysis of yam dioscorin A (Q9M519). Figure S2. The computer-aided simulation of pepsin hydrolysis of yam dioscorin B (Q9M501).

\section{Competing interests}

The authors declare that they have no competing interests.

\section{Authors' contributions}

HJL and WCH participated the discussion and concepts of experimental designs, MS writing and revision; YSL and YLL performed the ACE inhibitory screening and oral administration in vivo experiments; GJW performed the vaso-relaxing experiments ex vivo. All authors read and approved the final manuscript.

\section{Acknowledgements}

The authors would like to express thanks to Ministry of Science and Technology, Republic of China (NSC 102-2313-B-038 -004 -MY3) for financial supports.

\section{Author details}

${ }^{1}$ Graduate Institute of Pharmacognosy, Taipei Medical University, Taipei, Taiwan. ${ }^{2}$ School of Pharmacy, Taipei Medical University, Taipei, Taiwan. ${ }^{3}$ Graduate Institute of Clinical Medical Science, China Medical University, Taichung, Taiwan. ${ }^{4}$ Department of Medical Research, China Medical University Hospital, Taichung, Taiwan. ${ }^{5}$ Department of Health and Nutrition Biotechnology, Asia University, Taichung, Taiwan. ${ }^{6}$ Department of Food Science, Yuanpei University, Hsinchu, Taiwan. ${ }^{7}$ Traditional Herbal Medicine Research Center, Taipei Medical University Hospital, Taipei, Taiwan.

Received: 11 April 2014 Accepted: 16 May 2014

Published: 7 June 2014

\section{References}

Cheung HS, Wang FL, Ondetti MA, Sabo EF, Cushman DW (1980) Binding of peptide substrates and inhibitors of angiotensin-converting enzyme. Importance of the $\mathrm{COOH}$-terminal dipeptide sequence. J Biol Chem 255:401-407

Conlan RS, Griffiths LA, Napier JA, Shewry PR, Mantell S, Ainsworth C (1995) Isolation and characterisation of CDNA clones representing the genes encoding the major tuber storage protein (dioscorin) of yam (Dioscorea cayenensis Lam.). Plant Mol Biol 28:369-380

Fujita H, Usui H, Kurahashi K, Yoshikawa M (1995) Isolation and characterization of ovokinin, a bradykinin B 1 agonist peptide derived from ovalbumin. Peptides 16:785-790

Fujita H, Yokoyama K, Yoshikawa M (2000) Classification and antihypertensive activity of angiotensin I-converting enzyme inhibitory peptides derived from food proteins. J Food Sci 65:564-569

Han CH, Liu JC, Fang SU, Hou WC (2013) Antioxidant activities of the synthesized thiol-contained peptides derived from computer-aided pepsin hydrolysis of yam tuber storage protein, dioscorin. Food Chem 138:923-930

Han CH, Lin YS, Lin SY, Hou WC (2014a) Antioxidant and antiglycation activities of the synthesised dipeptide, Asn-Trp, derived from computer-aided simulation of yam dioscorin hydrolysis and its analogue, GIn-Trp. Food Chem 147:195-202

Han CH, Lin YF, Lin YS, Lee TL, Huang WJ, Lin SY, Hou WC (2014b) Effects of yam tuber protein, dioscorin, on attenuating oxidative status and learning dysfunction in D-galactose-induced BALB/c mice. Food Chem Toxicol 65:356-363

Hernández-Ledesma B, Dávalos A, Bartolomé B, Amigo L (2005) Preparation of antioxidant enzymatic hydrolysates from alpha-lactalbumin and beta-lactoglobulin. Identification of active peptides by HPLC-MS/MS. J Agric Food Chem 53:588-593 
Hou WC, Liu JS, Chen HJ, Chen TE, Chang CF, Lin YH (1999a) Dioscorin, the major tuber storage protein of yam (Dioscorea batatas Decne) with carbonic anhydrase and trypsin inhibitor activities. J Agric Food Chem 47:2168-2172

Hou WC, Chen HJ, Lin YH (1999b) Dioscorins, the major tuber storage proteins of yam (Dioscorea batatas Decne), with dehydroascorbate reductase and monodehydroascorbate reductase activities. Plant Sci 149:151-156

Hou WC, Chen HJ, Lin YH (2000) Dioscorins from different Dioscorea species all exhibit both carbonic anhydrase and trypsin inhibitor activities. Bot Bull Acad $\operatorname{Sin}$ 41:191-196

Hou WC, Lee MH, Chen HJ, Liang WL, Han CH, Liu YW, Lin YH (2001) Antioxidant activities of dioscorin, the storage protein of yam (Dioscorea batatas Decne) tuber. J Agric Food Chem 49:4956-4960

Hsu FL, Lin YH, Lee MH, Lin CL, Hou WC (2002) Both dioscorin, the tuber storage protein of yam (Dioscorea alata Cv. Tainong No. 1), and its peptic hydrolysates exhibited angiotensin converting enzyme inhibitory activities. J Agric Food Chem 50:6109-6113

Kagebayashi T, Kontani N, Yamada Y, Mizushige T, Arai T, Kino K, Ohinata K (2012) Novel CCK-dependent vasorelaxing dipeptide, Arg-Phe, decreases blood pressure and food intake in rodents. Mol Nutr Food Res 56:1456-1463

Kobayashi Y, Fukuda T, Tanaka M, Matsui T (2012) The anti-atherosclerotic di-peptide, Trp-His, inhibits the phosphorylation of voltage-dependent L-type $\mathrm{Ca}^{2+}$ channels in rat vascular smooth muscle cells. FEBS Open Bio 2:83-88

Kontani N, Omae R, Kagebayashi T, Kaneko K, Yamada Y, Mizushige T, Kanamoto R, Ohinata K (2014) Characterization of lle-His-Arg-Phe, a novel rice-derived vasorelaxing peptide with hypotensive and anorexigenic activities. Mol Nutr Food Res 58:359-364

Lin CL, Lin SY, Lin YH, Hou WC (2006) Effects of tuber storage protein of yam (Dioscorea alata cv. Tainong No. 1) and its peptic hydrolyzates on spontaneously hypertensive rats. J Sci Food Agric 86:1489-1494

Liu YH, Liang HJ, Cheng HC, Liu YW, Hou WC (2006) Comparisons of in vitro antioxidant activities of storage proteins in tuber of two Dioscorea species. Bot Stud 47:231-237

Liu YW, Shang HF, Wang CK, Hsu FL, Hou WC (2007) Immunomodulatory activity of dioscorin, the storage protein of yam (Dioscorea alata cv. Tainong No. 1) tuber. Food Chem Toxicol 45:2312-2318

Liu DZ, Liang HJ, Han CH, Lin SY, Chen CT, Fan M, Hou WC (2009a) Feeding trial of instant food containing lyophilised yam powder in hypertensive subjects. J Sci Food Agric 89:138-143

Liu YW, Liu JC, Huang CY, Wang CK, Shang HF, Hou WC (2009b) Effects of oral administration of yam tuber storage protein, dioscorin, to BALB/C mice for 21-days on immune responses. J Agric Food Chem 57:9274-9279

Lu YL, Chia CY, Liu YW, Hou WC (2012) Biological activities and applications of dioscorins, the major tuber storage proteins of yam. J Tradit Complement Med 2:41-46

Mark KS, Davis TP (2000) Stroke: development, prevention and treatment with peptidase inhibitors. Peptides 21:1965-1973

Martínez-Maqueda D, Miralles B, Recio I, Hernández-Ledesma B (2012) Antihypertensive peptides from food proteins: a review. Food Funct 3:350-361

Matoba N, Usui H, Fujita H, Yoshikawa M (1999) A novel anti-hypertensinve peptide derived from ovalbumin induces nitric oxide-mediated vasorelaxation in an isolated SHR mesenteric artery. FEBS Lett 452:181-184

Mittra S, Singh M (1998) Possible mechanism of captopril induced endotheliumdependent relaxation in isolated rabbit aorta. Mol Cell Biochem 183:63-67

Rubin B, Antonaccio MJ, Horovitz ZP (1978) Captopril (SQ 14 225) (D-3-mercapto-2-methylpropanoyl-L-proline): a novel orally active inhibitor of angiotensin-converting enzyme. Prog Cardiovasc Dis 21:183-194

Tanaka M, Tokuyasu M, Matsui T, Matsumoto K (2008) Endothelium-independent vasodilation effect of di- and tri-peptides in thoracic aorta of SpragueDawley rats. Life Sci 82:869-875

Tanaka M, Watanabe S, Wang Z, Matsumoto K, Matsui T (2009) His-Arg-Trp potently attenuates contracted tension of thoracic aorta of Sprague-Dawley rats through the suppression of extracellular $\mathrm{Ca}^{2+}$ influx. Peptides 30:1502-1507
Wang GJ, Shum AY, Lin YL, Liao JF, Wu XC, Ren J, Chen CF (2001) Calcium channel blockade in vascular smooth muscle cells: major hypotensive mechanism of S-petasin, a hypotensive sesquiterpene from Petasites formosanus. J Pharmacol Exp Ther 297:240-246

Wang Z, Watanabe S, Kobayashi Y, Tanaka M, Matsui T (2010) Trp-His, a vasorelaxant di-peptide, can inhibit extracellular $\mathrm{Ca}^{2+}$ entry to rat vascular smooth muscle cells through blockade of dihydropyridine-like L-type $\mathrm{Ca}^{2+}$ channels. Peptides 31:2060-2066

Zaman MA, Oparil S, Calhoun DA (2002) Drugs targeting the renin-angiotensinaldosterone system. Nat Rev Drug Discov 1:621-636

doi:10.1186/s40529-014-0049-3

Cite this article as: Lin et al:: Vasorelaxing and antihypertensive activities of synthesized peptides derived from computer-aided simulation of pepsin hydrolysis of yam dioscorin. Botanical Studies 2014 55:49.

\section{Submit your manuscript to a SpringerOpen ${ }^{\odot}$ journal and benefit from:}

- Convenient online submission

- Rigorous peer review

- Immediate publication on acceptance

- Open access: articles freely available online

- High visibility within the field

- Retaining the copyright to your article

Submit your next manuscript at $\gg$ springeropen.com 